\title{
Population genetics of the fish Brycon henni (Characiformes: Bryconidae) using species-specific polymorphic microsatellite loci
}

\author{
Ricardo M. Landínez-García ${ }^{1} \&$ Edna J. Márquez ${ }^{1 *}$ \\ 1. Facultad de Ciencias, Universidad Nacional de Colombia, Medellín, Colombia,Carrera 65 No 59A-110 Bloque 19 A \\ Laboratorio 310, Medellín, Colombia; rmlandin@unal.edu.co, ejmarque@unal.edu.co, ejmarque@gmail.com \\ * Correspondence
}

Received 22-VII-2019. C Corrected 28-II-2020. Accepted 01-VI-2020.

\begin{abstract}
Introduction: The freshwater fish Brycon henni (Characiformes: Bryconidae) is endemic to Colombia and currently considered as a "least concern" species according to the International Union for Conservation of Nature (IUCN). Objective: To develop microsatellite markers to examine population genetics in B. henni. Methods: Using a low-coverage sequencing genomic library, this study developed the first set of microsatellite loci to study the population genetics of this Neotropical species. These loci were used to evaluate the genetic diversity and structure of $B$. henni from three sites of the Magdalena-Cauca Basin (Colombia). Results: A set of 21 polymorphic microsatellite loci was highly informative and revealed that $B$. henni exhibits genetic diversity (5.143-5.619 alleles/locus, observed and expected heterozygosity $=0.461-0.645$ and $0.604-$ 0.662 , respectively) and is evenly genetically structured between two tributaries of the Cauca River separated by only $30 \mathrm{~km}\left(\mathrm{~F}_{\mathrm{ST}}^{\prime}=0.093\right.$, Jost's $\left.\mathrm{D}_{\mathrm{EST}}=0.311, \mathrm{P}<0.001\right)$ a finding that indicates these may be reproductively isolated groups. Conclusions: We reported a set of 21 polymorphic microsatellite loci that allowed the detection of genetic structure at local and regional scales. This population genetic structure, concordant with that found in eight congeners, is relevant when determining the risk categorization of $B$. henni, as well as management, conservation, and restocking programs for this species.
\end{abstract}

Key words: next-generation sequencing; molecular markers; genetic structure; genetic diversity; Neotropical fish; sabaleta; conservation.

Landínez-García, R.M. \& Márquez, E.J. (2020). Population genetics of the fish Brycon henni (Characiformes: Bryconidae) using species-specific polymorphic microsatellite loci. Revista de Biología Tropical, 68(3), 847-861.

Brycon is a polyphyletic genus of the family Bryconidae (Abe, Mariguela, Avelino, Foresti, \& Oliveira, 2014) that supports subsistence and commercial fisheries, sport fishing, and aquaculture in Central and South America (Zaniboni-Filho, Reynalte-Tataje, \& Weingartner, 2006). Although its systematics remain unclear, it is believed to encompass 43 valid species distributed from Southern Mexico to Northern Argentina (Angulo \& GracianNegrete, 2013; Lima, 2004). The major species diversity occurs in Panama and the Colombian and Ecuadorian trans-Andean rivers (Lima, 2003). Some Brycon species are listed in several risk categories, while others have deficient data for risk categorization and remain considered either as "least concern" based on their wide distribution or are not currently included in the Red List of the International Union for Conservation of Nature (IUCN).

Brycon henni Eigenmann, 1913 is a trans-Andean freshwater fish distributed in the Colombian Magdalena-Cauca and Pacific hydrographic regions (DoNascimiento, 
Herrera-Collazos, \& Maldonado-Ocampo, 2018). Brycon henni reproductive periods appear to be synchronized to rainy periods in natural environments (Builes \& Urán, 1974; Mancera-Rodríguez, 2017), but may occur during the entire year in some dams that do not experience drastic changes in water level depth (Martínez-Orozco \& Vásquez-Zapata, 2001). In contrast to the asynchronous oocyte maturity and incomplete spawning found in this species in other areas (Builes \& Urán, 1974), the similar maturity stage of $B$. henni oocytes in the Nare and Guatapé Rivers has led researchers to propose that this species performs seasonal and cyclic reproduction with short and massive spawning, without parental care, and exhibits moderate fecundity and reproductive migrations (Mancera-Rodríguez, 2017).

Furthermore, its fishery statistics are absent (Colombian Fishing Statistical Service, SEPEC) even though $B$. henni is locally considered as part of food security in riverine communities (Lasso et al., 2010), used for sport fishing especially in the upper and middle sections of the Cauca River, and is a promissory resource for commercial temperate-zone aquaculture (Cruz-Casallas, Medina-Robles, \& Velasco-Santamaría, 2011; Montoya-López, Carrillo, \& Olivera-Ángel, 2006). Additionally, information about species reintroductions remains unknown due to the lack of programmatic monitoring for fish translocations or fishing (FAO, 2011; Povh et al., 2008).

Although it is considered as a "least concern" species, B. henni is susceptible to the harmful effects of habitat disturbances, given that it requires good quality waters (Builes \& Urán, 1974; Lasso et al., 2010). Moreover, this species has a short-distance migration range between main river channels and adjacent highgradient streams (lateral migration) (Builes \& Urán, 1974; Lasso et al., 2010), a fact that suggests its natural populations are not panmictic along its distribution range. Indeed, genetically structured populations have been found for $B$. henni (Hurtado-Alarcón, Mancera-Rodríguez, \& Saldamando-Benjumea, 2011; Pineda-Santis et al., 2007) and other congeners such as
Brycon hilarii (Sanches \& Galetti Jr., 2007, 2012), Brycon insignis (Matsumoto \& Hilsdorf, 2009), Brycon lundii (Wasko \& Galetti Jr., 2002), Brycon moorei sinuensis (López, 2006), Brycon opalinus (Melon-Barroso, Hilsdorf, Moreira, Cabello, \& Traub-Cseko, 2005), Brycon orbignyanus (Ashikaga, Orsi, Oliveira, Senhorini, \& Foresti, 2015; Panarari-Antunes et al., 2011), and Brycon orthotaenia (Sanches et al., 2012).

Currently, only two genetic studies have been performed in $B$. henni at the regional scale using dominant markers, Random Amplification of Polymorphic DNA (RAPD) (HurtadoAlarcón et al., 2011; Pineda-Santis et al., 2007). Nonetheless, RAPDs exhibit several disadvantages such as low reproducibility, subjective determination of the real band, homoplasy, inability to detect heterozygotes, and greater sampling variance for dominant allele frequencies compared to codominant alleles (Çiftci, 2003; Lynch \& Milligan, 1994).

Forty-four microsatellites have been developed for three cis-Andean Brycon species (Melon-Barroso et al., 2005; Sanches \& Galetti Jr., 2012; Viana \& Vasconcelos de Macêdo, 2016). Nonetheless, different authors have indicated that the transferability of heterologous microsatellites is limited by unsuccessful amplification in phylogenetically distant species or lower levels of polymorphism, allele size homoplasy, null alleles, interrupted repeat motifs, and even amplification of non-orthologous loci (Barbará et al., 2007; Primmer, Painter, Koskinen, Palo, \& Merilä, 2005; Rutkowski, Sielezniew, \& Szostak, 2009; Yue, Balazs, \& Laszlo, 2010).

Considering the above constraints, we took advantage of the low-coverage sequenced genomic library of one $B$. henni specimen collected in the Colombian Cauca River (Landínez-García, Alzate, \& Márquez, 2016) to develop the first set of $B$. henni microsatellite loci. Likewise, we used these loci to study genetic diversity and population structure at a local (less than $30 \mathrm{~km})$ and regional $(600 \mathrm{~km})$ scale using samples from three natural populations of this species. These tools will allow 
researchers to elucidate/hypothesize the causes of $B$. henni population genetic structure across its distribution area and can be applied in the future to monitor genetic diversity changes in regions influenced by anthropogenic activities as well as support restocking and reinforcement programs.

\section{MATERIALS AND METHODS}

Samples and studied area: This study analyzed a total of $90 \mathrm{~B}$. henni tissues preserved in $70 \%$ ethanol that were provided by Integral S. A., through two scientific cooperation agreements (September 19 ${ }^{\text {th }}, 2013$; Grant CT-2013-002443), framed under an environmental permit from Ministerio de Ambiente, Vivienda y Desarrollo Territorial de Colombia \# 0155 on January $30^{\text {th }}$, 2009 for the Ituango hydropower plant construction. The samples, collected from 2011 to 2013, came from three sites of the Colombian MagdalenaCauca hydrographic region (Fig. 1A); in two of them (Ituango River $=19$ samples and Espíritu
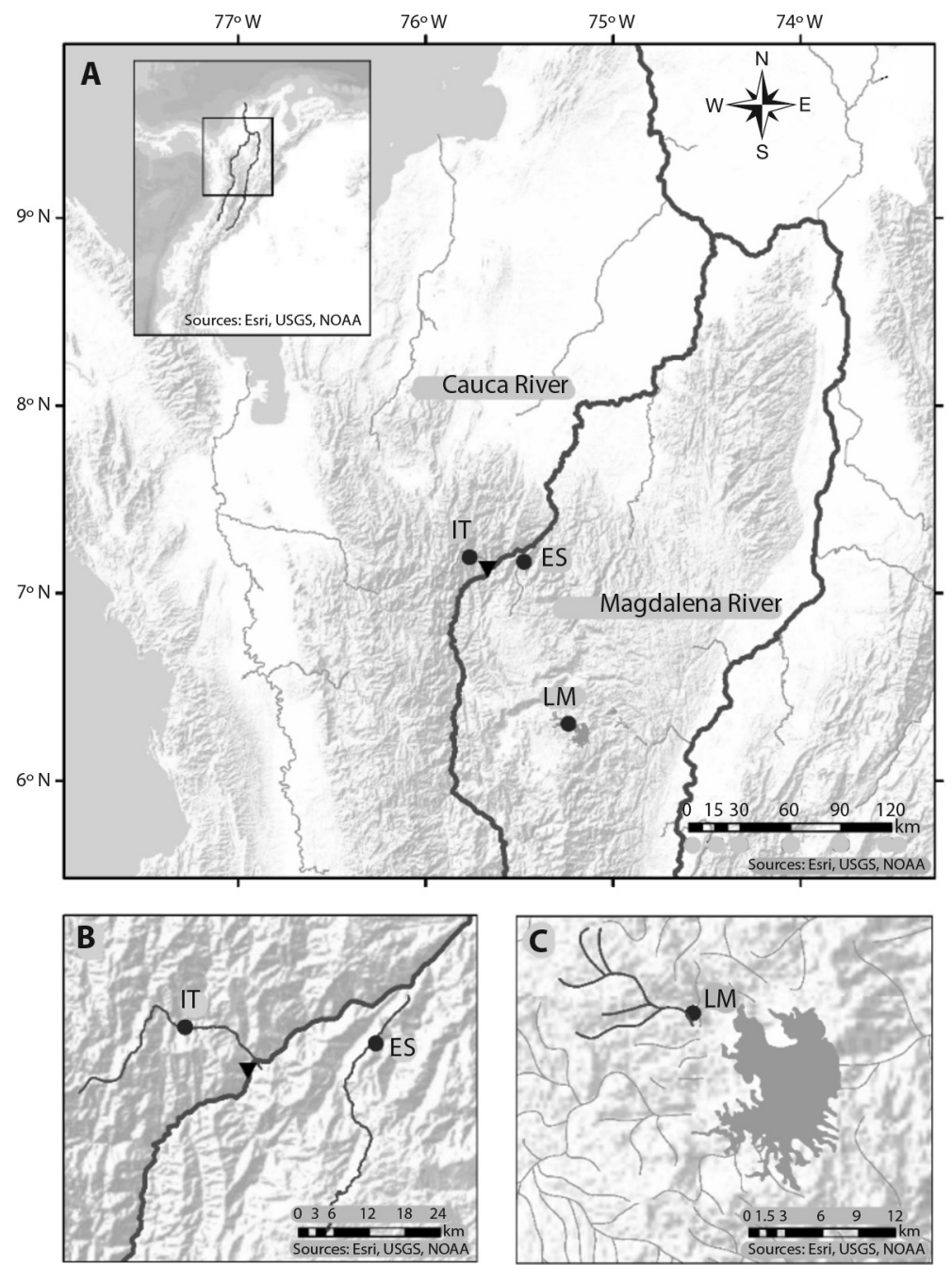

Fig. 1. Brycon henni sampling sites (dark circles) in three sectors of the (A) Colombian Magdalena-Cauca hydrographic region: (B) the Cauca River (IT, Ituango River; ES, Espíritu Santo River) and (C) the Magdalena River (La Magdalena Stream). The black triangle denotes the location of the Ituango hydropower plant. 
Santo River $=44$ samples) (Fig. 1B) samples were collected before the construction of the Ituango hydropower station in the Cauca River. The other site is located upstream of the PeñolGuatapé dam (La Magdalena Stream, a tributary of the Nare River $=27$ samples) (Fig. 1C).

The Ituango (IT) and Espíritu Santo (ES) rivers drain on the West and East margins of the Cauca River, respectively, and are separated by only $30 \mathrm{~km}$. This area, subjected to mining, agriculture, and artisanal and sport fisheries, corresponds to sections 2 and 3 of the Cauca River as described previously by Landínez-García and Márquez (2016). These areas feature steep topography with deep canyons, riverbed narrowing, and drastic changes in water velocities and slopes. On the other hand, La Magdalena Stream (LM) exhibits lower slopes and water levels, sandy and rocky substrates, and relatively turbid waters due to surrounding urban centers and paths that expose it to anthropic activities (for example, litter, erosion, sewage discharges, and agrochemical lixiviates).

Microsatellite loci identification and primer development: To identify microsatellite loci and develop primers, we used reads obtained from the genomic library of one $B$. henni specimen collected in the Cauca River (Colombia) that was previously sequenced with the Illumina Miseq platform using the whole genome shotgun strategy and 250 base pairedend reads (Landínez-García et al., 2016). Cleaning of nuclear genome reads, assemblage into contigs, primer design, electronic polymerase chain reaction (PCR), polymorphism analysis, validation, and amplification condition optimization for 50 microsatellite loci were performed following the methodology described by Landínez-García and Marquez (2016).

Briefly, the reads of the nuclear genome were submitted to PRINSEQ-LITE software to clean and eliminate short sequences (less than 100 base pairs [bp]), duplicated reads, and low-quality regions at both read ends and then assembled them into contigs with ABYSS v.1.3.5 (Simpson et al., 2009) using a Kmer 64.
Additionally, PAL_FINDER v.0.02.03 (Castoe et al., 2010) was used to extract the contigs that contained microsatellite loci with perfect motifs of $3 \mathrm{mer}$, $4 \mathrm{mer}$, and $5 \mathrm{mer}$ repeats. These longer motifs were selected to avoid genotyping errors associated with dinucleotide motifs (Guichoux et al., 2011; Schoebel et al., 2013). PRIMER3 v.2.0 (Rozen \& Skaletsky, 2000) was used to design the primers for microsatellite loci amplification from their flanking sequences and electronic PCR (Rotmistrovsky, Jang, \& Schuler, 2004) to verify correct primer alignment in silico (http://www.ncbi.nlm.nih. gov/tools/epcr/).

Levels of polymorphism and sample genotyping: A total of 50 microsatellite loci were selected for optimization and analysis of levels of polymorphism in $15 \mathrm{~B}$. henni samples using standard PCR conditions (Sambrook, Fritsch, \& Maniatis, 2001); amplified fragments were separated with silver-stained polyacrylamide gels. Polymorphic loci that exhibited consistent amplification, good band resolution, specificity, desired fragment size (100-400 bp), and heterozygosity in the analyzed samples were selected and fluorescently labelled for further amplification of 90 samples from three different sites.

Amplification reactions were $10 \mu \mathrm{l}$ and contained the following final component concentrations: $0.6 \mathrm{pmol} / \mu \mathrm{l}$ of each forward primer, attached by its 5 , end to one of the four adapters (Tails A, B, C and D) described by Blacket, Robin, Good, Lee, \& Miller (2012), $1.2 \mathrm{pmol} / \mu \mathrm{l}$ of each reverse primer, $1.0 \mathrm{pmol} / \mu \mathrm{l}$ of each fluorescently labelled adapter (6-FAM, VIC, NED, and PET; Applied Biosystems), $0.22 \mathrm{X}$ Master Mix, $2.5 \% \mathrm{v} / \mathrm{v}$ GC Enhancer Platinum Multiplex PCR Master Mix (Applied Biosystems), and 3-5 ng/ $\mu \mathrm{l}$ of template DNA isolated with GeneJET Genomic DNA Purification kit (Thermo Scientific). PCR was performed using a T100 thermocycler (BioRad) with the following thermal profile: initial denaturation at $95{ }^{\circ} \mathrm{C}$ for $3 \mathrm{~min}$ and 42 cycles of denaturation at $90{ }^{\circ} \mathrm{C}$ for $22 \mathrm{~s}$ and annealing 
at $56{ }^{\circ} \mathrm{C}$ for $20 \mathrm{~s}$. There were no extension and final elongation steps.

PCR products were submitted to electrophoresis, using LIZ500 (Applied Biosystems) as an internal molecular size on an ABI 3730 XL automated sequencer (Applied Biosystems), and GENEMAPPER v.4.0 (Applied Biosystems) was used to denote the allelic fragments according to their molecular size. Potential genotyping errors and null alleles were evaluated using MICRO-CHECKER v.2.2.3 (van Oosterhout, Hutchinson, Wills, \& Shipley, 2004).

Genetic diversity: The average number of alleles per locus was calculated using GENALEX v.6.503 (Peakall \& Smouse, 2006), and estimation of the observed $\left(\mathrm{H}_{\mathrm{O}}\right)$ and expected $\left(\mathrm{H}_{\mathrm{E}}\right)$ heterozygosities, inbreeding coefficient $\left(\mathrm{F}_{\mathrm{IS}}\right)$, as well as the tests for departures from Hardy-Weinberg and Linkage equilibria, were performed using ARLEQUIN v.3.5.2.2 (Excoffier, Laval, \& Schneider, 2005). Statistical significance for multiple comparisons was adjusted by applying the sequential Bonferroni correction (Rice, 1989). The polymorphic information content (PIC) for each marker was determined using CERVUS v.3.0.7 (Marshall, Slate, Kruuk, \& Pemberton, 1998).

Genetic structure: Genetic differentiation among samples from the three sites was calculated using the standardized statistics F' (Meirmans, 2006) and Jost's $\mathrm{D}_{\mathrm{EST}}$ (Meirmans \& Hedrick, 2011), as well as an analysis of molecular variance (AMOVA; (Meirmans, 2006) included in GENALEX v.6.503 (Peakall \& Smouse, 2006). Additionally, R package Adegenet (Jombart, 2008) was used to accomplish the discriminant analysis of principal components of the diploid genotypes of 21 loci (42 variables) in 90 individuals. A total of 42 principal components were retained for subsequent discriminant analysis and the first two linear discriminants that explained more than $80 \%$ of the total variation were used to construct a scatter plot.
Finally, STRUCTURE v.2.3.4 was used for Bayesian analysis of population partitioning (Pritchard, Stephens, \& Donnelly, 2000) to test genetic differentiation among and within sample sites. The run length that reached convergence consisted of 500000 Monte Carlo Markov Chain (MCMC) steps and 45000 iterations as burn-in. To improve the performance of the algorithm when the signal of the structure was relatively weak, the LOCPRIOR option was set, and the admixture model and correlated frequencies parameters were used (Hubisz, Falush, Stephens, \& Pritchard, 2009). For each simulated $\mathrm{K}$ value, which ranged from 1 to 6 , the analysis was repeated 20 times and the $\Delta \mathrm{K}$ ad hoc statistic (Evanno, Regnaut, \& Goudet, 2005) was calculated with STRUCTURE HARVESTER (Earl \& VonHoldt, 2012) for the best estimate of genetic stocks (K). CLUMPP v.1.1.2b (Jakobsson \& Rosenberg, 2007) was used to summarize the results of independent STRUCTURE runs; we selected the algorithm full search with the function G'normalized, and the parameters were set at their default values. The Q-matrices obtained were plotted in a histogram that displayed the ancestry of each individual in each population using DISTRUCT v.1.1 (Rosenberg, 2004). Based on the ancestry coefficients provided by STRUCTURE and CLUMPP, the individuals were reorganized by genetic stock in sample sites that showed multiple stocks and were later submitted to the genetic analyses described below.

\section{RESULTS}

Microsatellite loci development and detection of outlier loci: A set of 21 of the 50 initially evaluated loci satisfied the selection criteria described above (Table 1). Allele lengths ranged from 124 to $317 \mathrm{bp}$, and the number of alleles per locus oscillated from 4 to 13 , with an average number of 8.500 alleles per locus (Table 1). Micro-Checker analysis did not indicate any scoring errors attributable to stuttering, null alleles, or large allele dropout at the loci. Pairwise tests of genotypic disequilibrium were not significant and allelic frequencies 


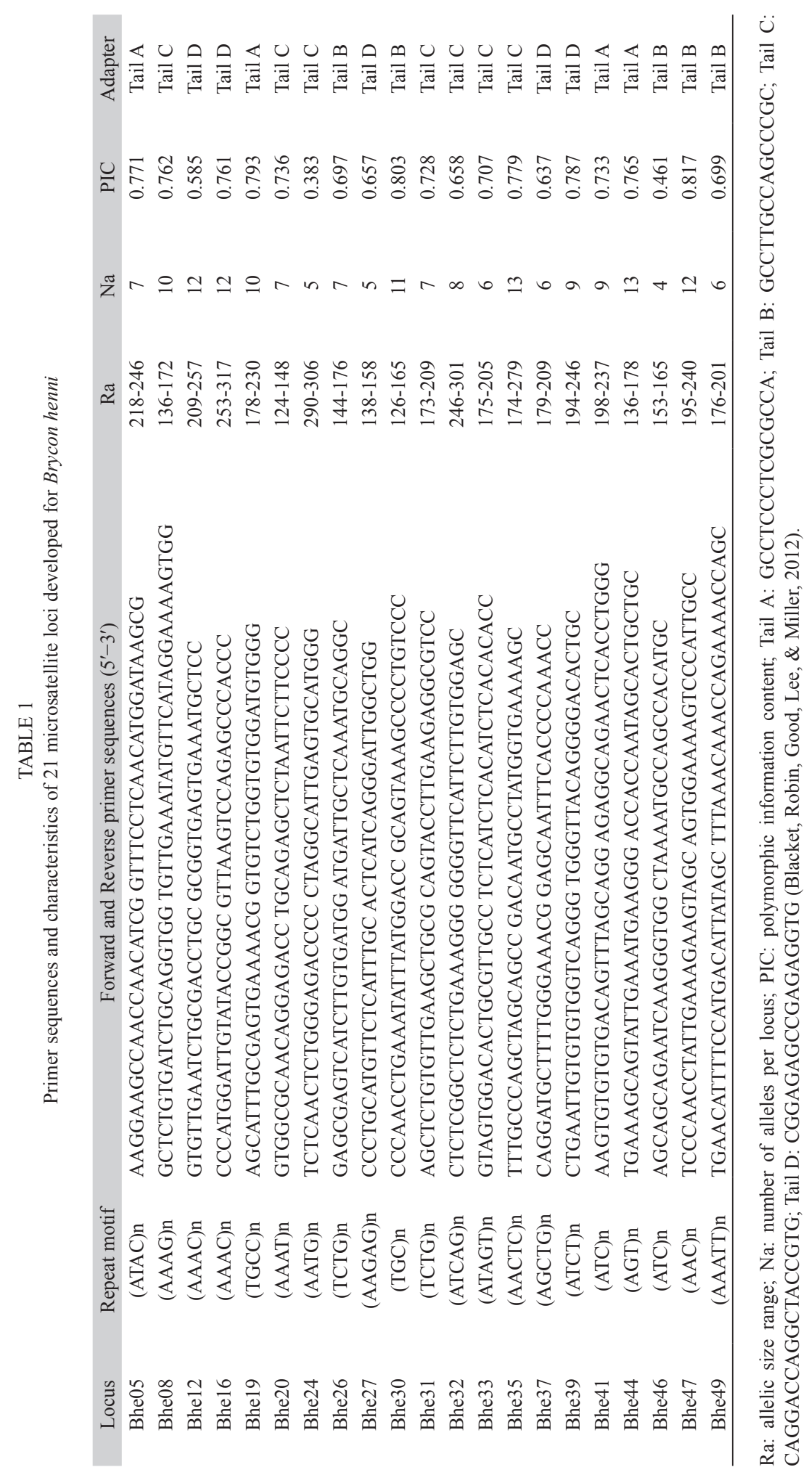




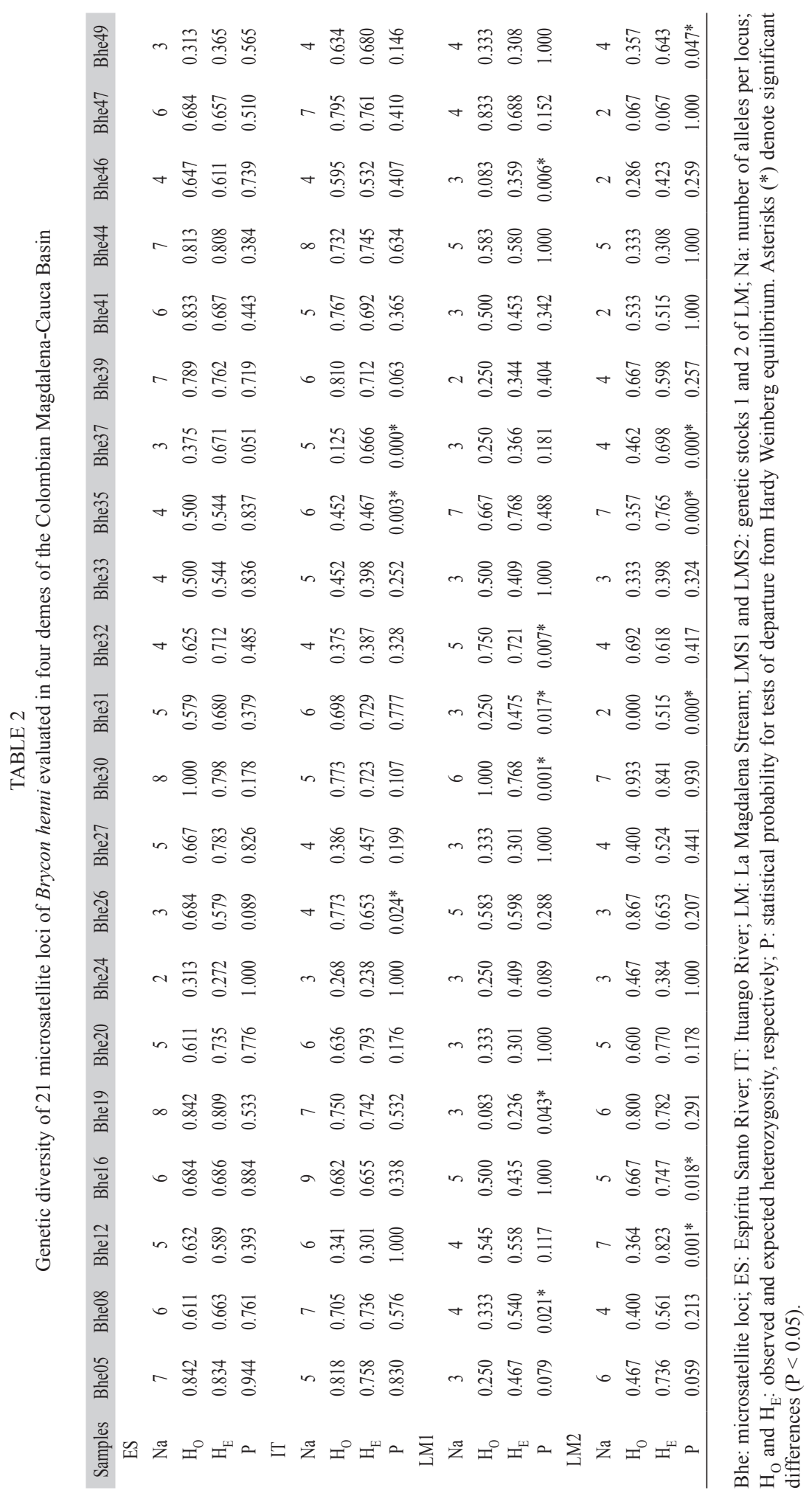


TABLE 3

Genetic diversity of Brycon henni from three sites of the Colombian Magdalena-Cauca Basin

\begin{tabular}{cccccccc} 
Site & $\mathrm{N}$ & $\mathrm{Na}$ & $\mathrm{H}_{\mathrm{O}}$ & $\mathrm{H}_{\mathrm{E}}$ & $\mathrm{P}_{\mathrm{HWE}}$ & $\mathrm{F}_{\text {IS }}$ & $\mathrm{P}_{\mathrm{FIS}}$ \\
ES & 19 & 5.143 & 0.645 & 0.638 & 0.372 & -0.048 & 0.894 \\
$\mathrm{IT}$ & 44 & 5.524 & 0.598 & 0.604 & 0.773 & -0.009 & 0.645 \\
LM & 27 & 5.619 & 0.461 & 0.662 & $0.000^{*}$ & 0.303 & $<0.001^{*}$ \\
LMS1 & 12 & 3.857 & 0.439 & 0.460 & $0.001^{*}$ & 0.086 & 0.112 \\
LMS2 & 15 & 4.238 & 0.479 & 0.568 & $0.000^{*}$ & 0.151 & $0.007^{*}$ \\
\hline
\end{tabular}

ES: Espíritu Santo River; IT: Ituango River; LM: La Magdalena Stream; LMS1 and LMS2: stocks 1 and 2 of LM. Na: number of alleles per locus; $\mathrm{H}_{\mathrm{O}}$ and $\mathrm{H}_{\mathrm{E}}$ : observed and expected heterozygosity, respectively; $\mathrm{F}_{\mathrm{IS}}$ : inbreeding coefficient; $\mathrm{P}_{\mathrm{HWE}}$ and $\mathrm{P}_{\mathrm{FIS}}$ : statistical probability for tests of departure from Hardy Weinberg equilibrium and inbreeding coefficient, respectively. Asterisks (*) denote significant differences.

were concordant with Hardy-Weinberg equilibrium expectations in at least 2 of 4 analyzed samples indicating that heterozygote deficit or excess detected in some cases depends on genetic characteristics of the sample (Table 2).

Genetic diversity: Compared with IT, the individuals collected in ES exhibited lower average number of alleles per locus and higher values of observed and expected heterozygosity (Table 3 ). In both cases, the allelic frequencies were concordant with Hardy-Weinberg equilibrium expectations, and the inbreeding coefficients were not significant (Table 3). Additionally, LM displayed the highest number of alleles per locus, a highly significant heterozygosity deficit, and a significant inbreeding coefficient (Table 3). These levels of genetic diversity and inbreeding were higher than those showed by two stocks of LM (LMS1 and LMS2, Table 3) revealed by the genetic structure analysis.

Genetic structure: The most supported number of clusters using the $\Delta \mathrm{K}$ method was $\mathrm{K}$ $=2[$ Mean $\operatorname{LnP}(\mathrm{K})=-5152.045]$, one predominantly in the Cauca River basin and the other in the La Magdalena Stream (Fig. 2A). However, an additional clustering pattern $(\mathrm{K}=4)$ was examined to compare it with other approaches, showing genetic differences between the IT and ES and within LM (Fig. 2B). Genetic differences among sites were corroborated by discriminant analysis of principal components
(Fig. 2C), AMOVA (F' ${ }_{\text {ST }(2,179)}=0.179, \mathrm{P}<$ $0.001)$, and the pair-wise standardized statistics $\mathrm{F}_{\mathrm{ST}}$ and Jost's $\mathrm{D}_{\mathrm{EST}}$ (Table 4).

\section{DISCUSSION}

The relevant results from this study concern the development of a set of 21 polymorphic microsatellite loci for $B$. henni. The novel species-specific microsatellite loci included perfect motifs of $5 \mathrm{mer}$ (7), $4 \mathrm{mer}$ (10), and $3 \mathrm{mer}$ (4) repeats that exhibited consistent amplification, good band resolution, expected fragment size, high polymorphism levels and satisfied the assumptions of Hardy-Weinberg and Linkage equilibria.

It is expected that shorter motifs (e.g. 2 mers) tend to be more variable, but practical matters related with scoring variability in shorter motifs can lead to uncertain motif length, difficulty in interpreting results, and possible

TABLE 4

Pairwise Jost's $\mathrm{D}_{\text {EST }}$ (above diagonal) and F' (below diagonal) among samples of Brycon henni from the Magdalena-Cauca Basin, Colombia

\begin{tabular}{cccc} 
& IT & ES & LM \\
IT & & $0.311^{*}$ & $0.521^{*}$ \\
ES & $0.093^{*}$ & & $0.465^{*}$ \\
LM & $0.135^{*}$ & $0.117^{*}$ & \\
\hline
\end{tabular}

IT: Ituango River; ES: Espíritu Santo River; LM: La Magdalena Stream. Asterisks $(*)$ denote significant differences $(\mathrm{P}<0.001)$. 

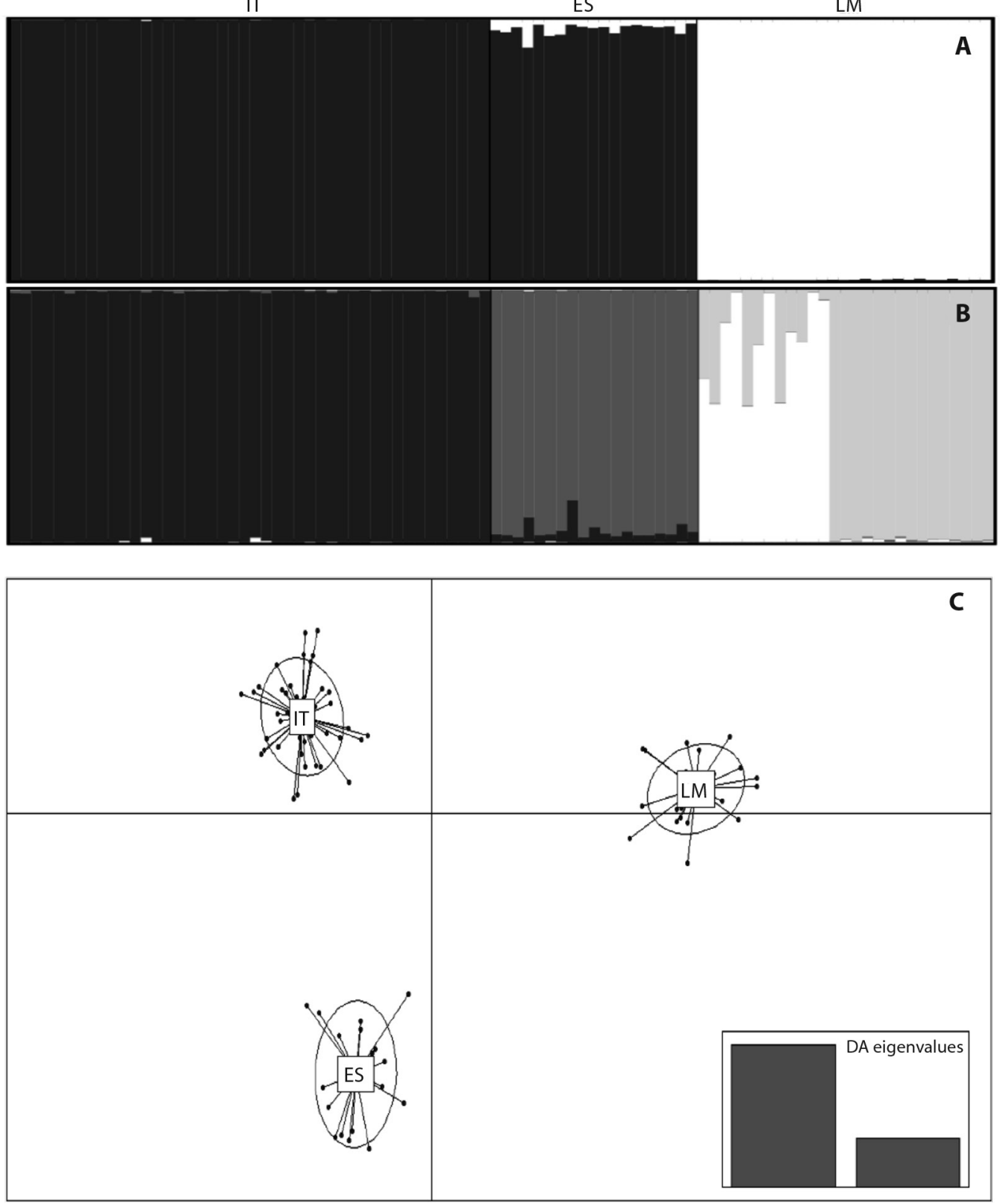

Fig. 2. Population structure bar plots estimated by STRUCTURE software for (A) $K=2$, (B) $K=4$ and (C) discriminant analysis of principal components in three sites of the Magdalena-Cauca hydrographic region. IT: Ituango River; ES: Espíritu Santo River; LM: La Magdalena Stream. 
allele misclassification (Castoe et al., 2012). Hence, although they might exhibit lower polymorphism levels, the longer repeat motifs were selected in this study to avoid genotyping errors associated with 2 mer motifs (Guichoux et al., 2011; Schoebel et al., 2013).

Lack of previous information about $B$. henni microsatellite loci and the differences in repeat motif lengths with its congeners did not allow us to compare the results of average number of alleles per locus from this work with previous studies of this species' population genetics (Hurtado-Alarcón et al., 2011; Pineda-Santis et al., 2007) and other Brycon species (Melon-Barroso et al., 2005; Sanches \& Galetti Jr., 2012; Viana \& Vasconcelos de Macêdo, 2016). However, as discussed below, these novel loci seem able to measure reliable levels of genetic diversity.

Considering the differences in the repeat motif lengths and their probable relationships with differential mutational rates (Castoe et al., 2012; del Giudice et al., 2001), we recommend the use of heterozygosity levels rather than the average number of alleles per locus to compare the genetic diversity of $B$. henni with available reports of other congeners.

The levels of observed (0.461-0.645) and expected (0.604-0.662) heterozygosities were in the range of average heterozygosity per species across microsatellite loci $\left(\mathrm{H}_{\mathrm{O}}\right.$ : 0.189$0.880 ; \mathrm{H}_{\mathrm{E}}: 0.486-0.892$ ) found in seven Brycon species (Ashikaga et al., 2015; López, 2006; Matsumoto \& Hilsdorf, 2009; MelonBarroso et al., 2005; Sanches \& Galetti Jr., 2012; Sanches et al., 2012) and Neotropical Characiforms (Hilsdorf \& Hallerman, 2017). Specifically, the average expected $B$. henni heterozygosities were higher than those observed in B. orbignyanus (Ashikaga et al., 2015), similar to B. moorei sinuensis (López, 2006) and B. hilarii (Sanches \& Galetti Jr., 2012), but lower than B. opalinus (Melon-Barroso et al., 2005), $B$. insignis (Matsumoto \& Hilsdorf, 2009), B. orthotaenia (Sanches et al., 2012), and B. amazonicus (Oliveira, Santos, Bernardino, Hrbek, \& Farias, 2018).
However, the average observed $B$. henni heterozygosities in IT and ES were higher than those found in B. hilarii (Sanches \& Galetti Jr., 2012), B. opalinus (Melon-Barroso et al., 2005), B. moorei sinuensis (López, 2006), and B. orbignyanus (Ashikaga et al., 2015), and lower than B. orthotaenia (Sanches et al., 2012) and B. insignis (Matsumoto \& Hilsdorf, 2009). In LM, the average observed $B$. henni heterozygosities were only higher than those found in B. moorei sinuensis (López, 2006) and B. orbignyanus (Ashikaga et al., 2015).

Brycon henni samples of ES and IT showed similar values of expected and observed heterozygosities, concordant with Hardy-Weinberg and Linkage equilibria. Alike findings were also found in B. hilarii from the Peixe and Miranda Rivers in the Paraguay River basin (Sanches \& Galetti Jr., 2012). In contrast, samples from LM exhibited a strong and significant heterozygosity deficit. Similar results were reported for B. opalinus (Melon-Barroso et al., 2005), B. moorei sinuensis (López, 2006), B. orthotaenia (Sanches et al., 2012), B. hilarii (Sanches \& Galetti Jr., 2012), and B. orbignyanus (Ashikaga et al., 2015).

Brycon henni external fertilization suggests that assortative mating does not explain the results of LM. Instead, the Wahlund effect may explain these results, especially considering the coexistence of two genetic stocks as discussed below. However, other causes like inbreeding may also explain the heterozygosity deficit as values of $\mathrm{F}_{\mathrm{IS}}$ were significant in total samples $\left(\mathrm{F}_{\mathrm{IS}}=0.303, \mathrm{P}<0.001\right)$ as well as in one $\left(\mathrm{F}_{\mathrm{IS}}=0.151, \mathrm{P}=0.007\right)$ of the two genetic stocks of LM.

The novel set of microsatellite loci provides evidence that $B$. henni populations exhibit a hierarchical genetic structure at the local and regional scales evaluated in this study. A regional genetic structure (Cauca tributaries and La Magdalena Stream) is concordant with results found in other sectors between the Magdalena (Humarada River, La Clara River) and Cauca (Piedras River, Guaracú River) Rivers (Pineda-Santis et al., 2007) and between the Nare and Guatapé Rivers 
(Hurtado-Alarcón et al., 2011) using dominant markers. This outcome is not surprising because $B$. henni exhibits a short-distance migration range $(<100 \mathrm{~km})$, and the Cauca tributaries are separated by $600 \mathrm{~km}$ from LM. However, the local scales provide new insights about the $B$. henni population structure. Pairwise comparisons of fixation and genetic differentiation indexes as well as discriminant analysis of principal components revealed genetic differences between ES and IT populations, a finding that is concordant with STRUCTURE analyses that considered $\mathrm{K}=4$, which also revealed the coexistence of two genetic stocks in LM.

The $B$. henni genetic differences between the tributaries of the Cauca River separated by less than $30 \mathrm{~km}$, and collected one year before beginning the construction Ituango hydropower station, may be explained by landscape characteristics, including steep topography and drastic changes in water velocities and slopes that may limit gene flow between the sampled localities, as was observed in this area with the Prochilodontidae member Ichthyoelephas longirostris using microsatellite loci (LandínezGarcía \& Márquez, 2016). Alternatively, this outcome may also be explained by $B$. henni behavioral features such as migration type since previous studies reported $B$. henni lateral migrations between tributaries and main river channels rather than longitudinal migrations (Builes \& Urán, 1974; Lasso et al., 2010), which may explain the limited gene flow along the main river channel. Additionally, this genetic structure may result from homing behavior as has been proposed in B. lundii (Wasko \& Galetti Jr., 2002) or high habitat requirements that might influence the distribution and/or reproductive behavior, as occurs in other tropical fish (Arantes, Castello, Cetra, \& Schilling, 2013; Guisande et al., 2012; Humphries, King, \& Koehn, 1999; Pareja-Carmona et al., 2014).

The coexistence of two genetic stocks in LM provides strong support to the hypothesis that the Wahlund effect explains the significant heterozygosity deficit found at this site. This idea is sustained by further analyses that showed most of loci exhibited allelic frequencies concordant with the Hardy-Weinberg equilibrium in each genetic stock. Lack of genetic information before dam construction in this area did not allow us to identify whether the presence of stocks in LM represents a natural or artificial genetic structure. Similar structuring has been observed in $B$. hilarii from the Paraguay River Basin (Sanches \& Galetti Jr., 2007, 2012), B. orthotaenia (Sanches et al., 2012), B. insignis (Matsumoto \& Hilsdorf, 2009), and B. opalinus from the Paraíba do Soul River Basin (Melon-Barroso et al., 2005), B. lundii in the Sao Francisco River (Brazil) (Wasko \& Galetti Jr., 2002), and B. orbignyanus from the upper Paraná River (Panarari-Antunes et al., 2011) and in the La Plata River Basin (Ashikaga et al., 2015). A temporal Wahlund effect is unlikely to explain our findings since $B$. henni apparently exhibits short, massive spawning, seasonal and cyclic reproduction, in this area (Mancera-Rodríguez, 2017). In contrast, the proposal that $B$. hilarii spawning schools may use different sites for reproduction and feeding (Sanches \& Galetti Jr., 2012), as well as homing behavior proposed in B. lundii (Wasko \& Galetti Jr., 2002), suggest that $B$. henni may exhibit a spatial Wahlund effect, but future studies are required to explore this hypothesis.

It remains to be determined in a larger sample size and number of localities whether $B$. henni populations are panmictic along their distribution range. This knowledge would be relevant to estimate the species risk categorization, which is currently considered as least concern due to its wide distribution. Based on their migration type, habitat requirements and presence in heterogeneous environments, we propose that $B$. henni populations conform to genetic patchiness along their distribution. This idea is supported by results published for seven studied congeners (Ashikaga et al., 2015; López, 2006; Matsumoto \& Hilsdorf, 2009; Melon-Barroso et al., 2005; Sanches \& Galetti Jr., 2012; Sanches et al., 2012; Wasko \& Galetti Jr., 2002). Together, these studies suggest that this genetic population structure is a generalized tendency in the Brycon genus, 
although B. amazonicus (Oliveira et al., 2018) seems to be an exception to this rule.

In conclusion, we reported a new set of 21 polymorphic microsatellite loci that was highly informative and allowed the detection of genetic structure at local and regional scales. Hence, they are strongly recommended for future studies of $B$. henni diversity and population genetics. Since the Cauca River tributary samples were collected before the construction of the Ituango hydropower station, these results constitute a baseline for monitoring future changes in the genetic diversity and structure of these B. henni populations. In the La Magdalena Stream, this study complements the available information, which is necessary to restructure the management plans for this species.

Ethical statement: authors declare that they all agree with this publication and made significant contributions; that there is no conflict of interest of any kind; and that we followed all pertinent ethical and legal procedures and requirements. All financial sources are fully and clearly stated in the acknowledgements section. A signed document has been filed in the journal archives.

\section{ACKNOWLEDGMENTS}

This work was funded by the Universidad Nacional de Colombia, Sede Medellín and Empresas Públicas de Medellín, Grant CT-2013-002443-R1 "Variación genotípica y fenotípica de poblaciones de especies reófilas presentes en el área de influencia del proyecto hidroeléctrico Ituango". Grant Convenio CT-2019-000661 "Variabilidad genética de un banco de peces de los sectores medio y bajo del Río Cauca". The authors thank the Centro Nacional de Secuenciación Genómica, Universidad de Antioquia (Medellín, Colombia) for assistance in bioinformatics analysis.

\section{RESUMEN}

Genética de poblaciones del pez Brycon henni (Characiformes: Bryconidae) utilizando loci microsatélites polimórficos especie-específicos. Introducción: El pez de agua dulce Brycon henni (Characiformes: Bryconidae) es una especie endémica de Colombia que actualmente está catalogada como de "menor preocupación" por la Unión Internacional para la Conservación de la Naturaleza (UICN). Objetivo: Desarrollar marcadores microsatélites para estudiar la genética poblacional de Brycon henni. Métodos: Usando una biblioteca genómica de secuenciación de baja cobertura, este estudio desarrolló el primer grupo de loci microsatélites para el estudio de la genética poblacional de esta especie neotropical. Estos loci fueron usados para evaluar la diversidad genética y estructura de $B$. henni en tres sitios de la cuenca Magdalena-Cauca (Colombia). Resultados: Un grupo de 21 loci polimórficos tipo microsatélite fueron altamente informativos y revelaron que $B$. henni exhibe diversidad genética (5.1435.619 alelos/locus, heterocigosidad observada y esperada $=$ 0.461-0.645 y $0.604-0.662$, respectivamente) y se encuentra genéticamente estructurado entre dos tributarios del río Cauca separados únicamente por $30 \mathrm{~km}\left(\mathrm{~F}^{\prime}{ }_{\mathrm{ST}}=0.093\right.$, Jost's $\left.\mathrm{D}_{\mathrm{EST}}=0.311, \mathrm{P}<0.001\right)$, un resultado que indica que puede existir aislamiento reproductivo entre dichos grupos. Conclusiones: Reportamos un grupo de 21 loci polimórficos tipo microsatélite que permitieron la detección de la estructura genética a escala local y regional. Esta estructura genética poblacional, concordante con lo que se reporta para otros ocho congéneres, es relevante al determinar la categorización de riesgo de $B$. henni, así como los programas de manejo, conservación y repoblamiento para esta especie.

Palabras clave: secuenciación de próxima generación; marcadores moleculares; estructura genética; diversidad genética; peces neotropicales; sabaleta; conservación.

\section{REFERENCES}

Abe, K.T., Mariguela, T.C., Avelino, G.S., Foresti, F., \& Oliveira, C. (2014). Systematic and historical biogeography of the Bryconidae (Ostariophysi: Characiformes) suggesting a new rearrangement of its genera and an old origin of Mesoamerican ichthyofauna. BMC Evolutionary Biology, 14(1), 152-167. DOI: https://doi.org/10.1186/1471-2148-14-152

Angulo, A., \& Gracian-Negrete, J.M. (2013). A new species of Brycon (Characiformes: Characidae) from Nicaragua and Costa Rica, with a key to the lower Mesoamerican species of the genus. Zoota$x a, 3731(2), 255-266$. DOI: https://doi.org/10.11646/ zootaxa.3731.2.6

Arantes, C.C., Castello, L., Cetra, M., \& Schilling, A. (2013). Environmental influences on the distribution of arapaima in Amazon floodplains. Environmental Biology of Fishes, 96(10-11), 1257-267. DOI: https:// doi.org/10.1007/s10641-011-9917-9 
Ashikaga, F.Y., Orsi, M.L., Oliveira, C., Senhorini, J.A., \& Foresti, F. (2015). The endangered species Brycon orbignyanus: Genetic analysis and definition of priority areas for conservation. Environmental Biology of Fishes, 98(3), 1845-1855. DOI: https://doi. org/10.1007/s10641-015-0402-8

Barbará, T., Palma-Silva, C., Paggi, G.M., Bered, F., Fay, M.F., \& Lexer, C. (2007). Cross-species transfer of nuclear microsatellite markers: Potential and limitations. Molecular Ecology, 16(18), 3759-3767. DOI: https://doi.org/10.1111/j.1365-294X.2007.03439.x

Blacket, M.J., Robin, C., Good, R.T., Lee, S.F., \& Miller, A.D. (2012). Universal primers for fluorescent labelling of PCR fragments-an efficient and cost-effective approach to genotyping by fluorescence. Molecular Ecology Resources, 12(3), 456-463. DOI: https://doi. org/10.1111/j.1755-0998.2011.03104.x

Builes, J., \& Urán, A. (1974). Estudio del ciclo sexual de la sabaleta Brycon henni Eigenmann. Su comportamiento y fecundación artificial. Actualidades Biológicas, 7, 2-12.

Castoe, T.A., Poole, A.W., Gu, W., Jason de Koning, A.P., Daza, J.M., Smith, E.N., \& Pollock, D.D. (2010). Rapid identification of thousands of copperhead snake Agkistrodon contortrix microsatellite loci from modest amounts of 454 shotgun genome sequence. Molecular Ecology Resources, 10(2), 341-347. DOI: https://doi.org/10.1111/j.1755-0998.2009.02750.x

Castoe, T.A., Poole, A.W., Jason de Koning, A.P., Jones, K.L., Tomback, D.F., Oyler-McCance, S.J., ... Streicher, J.W. (2012). Rapid microsatellite identification from Illumina Paired-End genomic sequencing in two birds and a snake. PLoS One, 7(2), e30953. DOI: https://doi.org/10.1371/journal.pone.0030953

Çiftci, Y. (2003). Fish population genetics and molecular markers: II- Molecular markers and their applications in fisheries and aquaculture. Turkish Journal of Fisheries and Aquatic Sciences, 79(3), 51-79.

Cruz-Casallas, P.E., Medina-Robles, V.M., \& VelascoSantamaría, Y.M. (2011). Fish farming of native species in Colombia: Current situation and perspectives. Aquaculture Research, 42(6), 823-831. DOI: https:// doi.org/10.1111/j.1365-2109.2011.02855.x

del Giudice, E.M., Santoro, N., Cirillo, G., D’Urso, L., Di Toro, R., \& Perrone, L. (2001). Mutational screening of the CART gene in obese children. Diabetes, 50(9), 2157 LP-2160. https://doi.org/10.2337/ diabetes.50.9.2157

DoNascimiento, C., Herrera-Collazos, E.E., \& Maldonado-Ocampo, J.A. (2018). Lista de especies de peces de agua dulce de Colombia. Asociación Colombiana de Ictiólogos, v2.10. DOI: https://doi. org/10.15472/numrso
Earl, D.A., \& vonHoldt, B.M. (2012). STRUCTURE HARVESTER: A website and program for visualizing STRUCTURE output and implementing the Evanno method. Conservation Genetics Resources, 4(2), 359-361. DOI: https://doi.org/10.1007/ s12686-011-9548-7

Evanno, G., Regnaut, S., \& Goudet, J. (2005). Detecting the number of clusters of individuals using the software Structure: A simulation study. Molecular Ecology, 14(8), 2611-2620. DOI: https://doi. org/10.1111/j.1365-294X.2005.02553.x

Excoffier, L., Laval, G., \& Schneider, S. (2005). Arlequin (version 3.0): An integrated software package for population genetics data analysis. Evolutionary Bioinformatics, 1, 47-50. DOI: https://doi.org/10.4137/ EBO.S0

FAO. (2011). Taller sobre repoblamiento de cuerpos de agua continentales en América Latina y el Caribe. Cuernavaca, México: FAO Organisation.

Guichoux, E., Lagache, L., Wagner, S., Chaumeil, P., Léger, P., Lepais, O., ... Petit, R.J. (2011). Current trends in microsatellite genotyping. Molecular Ecology Resources, 11(4), 591-611. DOI: https://doi. org/10.1111/j.1755-0998.2011.03014.x

Guisande, C., Pelayo-Villamil, P., Vera, M., ManjarrésHernández, A., Carvalho, M.R., Vari, R.P., ... Duque, S.R. (2012). Ecological factors and diversification among Neotropical Characiforms. International Journal of Ecology, 2012, 1-20. DOI: https://doi. org/10.1155/2012/610419

Hilsdorf, A.W.S., \& Hallerman, E.M. (2017). Genetic Resources of Neotropical Fishes (1st ed.). Cham, Switzerland: Springer International Publishing AG.

Hubisz, M.J., Falush, D., Stephens, M., \& Pritchard, J.K. (2009). Inferring weak population structure with the assistance of sample group information. Molecular Ecology Resources, 9(5), 1322-1332. DOI: https:// doi.org/10.1111/j.1755-0998.2009.02591.x

Humphries, P., King, A., \& Koehn, J. (1999). Fish, flows and flood plains: links between freshwater fishes and their environment in the Murray-Darling River system, Australia. Environmental Biology of Fishes, 56(1), 129-151. DOI: https://doi. org/10.1023/A:1007536009916

Hurtado-Alarcón, J.C., Mancera-Rodríguez, N.J., \& Saldamando-Benjumea, C.I. (2011). Variabilidad genética de Brycon henni (Characiformes: Characidae) en la cuenca media de los ríos Nare y Guatapé, sistema Río Magdalena, Colombia. Revista de Biología Tropical, 59(1), 269-282.

Jakobsson, M., \& Rosenberg, N.A. (2007). CLUMPP: A cluster matching and permutation program for dealing with label switching and multimodality in analysis of population structure. Bioinformatics, 
23(14), 1801-1806. DOI: https://doi.org/10.1093/ bioinformatics/btm233

Jombart, T. (2008). ADEGENET: A R package for the multivariate analysis of genetic markers. Bioinformatics, 24, 1403-1405. DOI: https://doi.org/10.1093/ bioinformatics/btn 129

Landínez-García, R.M., Alzate, J.F., \& Márquez, E.J. (2016). Complete mitogenome of the neotropical fish Brycon henni, Eigenmann 1913 (Characiformes, Bryconidae). Mitochondrial DNA Part A, 27(3), 2259-2260. DOI: https://doi.org/10.3109/19401736. 2014.984170

Landínez-García, R.M., \& Márquez, E.J. (2016). Development and characterization of 24 polymorphic microsatellite loci for the freshwater fish Ichthyoelephas longirostris (Characiformes: Prochilodontidae). PeerJ, 4, e2419. DOI: https://doi.org/10.7717/ peerj.2419

Lasso, C., Agudelo, E., Jimenez-Segura, L., Ramírez-Gil, H., Morales-Betancourt, M., Ajiaco-Martínez, R., ... Sanabria-Ochoa, A. (2010). Catálogo de los recursos pesqueros continentales de Colombia. Bogotá, Colombia: Instituto de Investigación de Recursos Biológicos Alexander von Humboldt (IAvH).

Lima, F.C.T. (2003). Subfamily Bryconinae. In R.E. Reis, S.O. Kullander, \& C.J. Ferraris (Eds.), Check List of the Freshwater Fishes of South and Central America (pp. 174-181). Porto Alegre, Brazil: EDIPUCRS.

Lima, F.C.T. (2004). Brycon gouldingi, a new species from the rio Tocantins drainage, Brazil (Ostariophysi: Characiformes: Characidae), with a key to the species in the basin. Ichthyological Exploration of Freshwaters, 15(3), 279-287.

López, L. (2006). Genetic variability and population structure of dorada (Brycon moorei sinuensis Dahl) in the Sinú River, Córdoba, Colombia. Lakes and Reservoirs: Research and Management, 11(1), 1-7. DOI: https://doi.org/10.1111/j.1440-1770.2006.00289.x

Lynch, M., \& Milligan, B.G. (1994). Analysis of population genetic structure with RAPD markers. Molecular Ecology, 3(2), 91-99.

Mancera-Rodríguez, N.J. (2017). Biología reproductiva de Brycon henni (Teleostei: Bryconidae) y estrategias de conservación para los ríos Nare y Guatapé, cuenca del río Magdalena, Colombia. Revista de Biología Tropical, 65(3), 1105-1119. DOI: https://doi. org/10.15517/rbt.v65i3.26826

Marshall, T.C., Slate, J., Kruuk, L.E., \& Pemberton, J.M. (1998). Statistical confidence for likelihoodbased paternity inference in natural populations. Molecular Ecology, 7(5), 639-655. DOI: https://doi. org/10.1046/j.1365-294x.1998.00374.x
Martínez-Orozco, H.J., \& Vásquez-Zapata, G. (2001). Aspectos reproductivos de la Sabaleta Brycon henni (Piscis: Characidae) en el embalse la Salvajina, Colombia. Dahlia, 4, 75-82.

Matsumoto, C.K., \& Hilsdorf, A.W.S. (2009). Microsatellite variation and population genetic structure of a neotropical endangered Bryconinae species Brycon insignis Steindachner, 1877: implications for its conservation and sustainable management. Neotropical Ichthyology, 7, 395-402. DOI: https://doi.org/http:// dx.doi.org/10.1590/S1679-62252009000300006

Meirmans, P.G. (2006). Using the AMOVA framework to estimate a standardized genetic differentiation measure. Evolution, 60, 2399-2402. DOI: https://doi. org/10.1111/j.0014-3820.2006.tb01874.x

Meirmans, P.G., \& Hedrick, P.W. (2011). Assessing population structure: Fst and related measures. Molecular Ecology Resources, 11, 5-18. DOI: https://doi. org/10.1111/j.1755-0998.2010.02927.x

Melon-Barroso, R., Hilsdorf, A.W.S., Moreira, H.L.M., Cabello, P.H., \& Traub-Cseko, Y.M. (2005). Genetic diversity of wild and cultured populations of Brycon opalinus (Cuvier, 1819) (Characiforme, Characidae, Bryconiae) using microsatellites. Aquaculture, 247(1-4), 51-65. DOI: https://doi.org/10.1016/j. aquaculture.2005.02.004

Montoya-López, A.F., Carrillo, L.M., \& Olivera-Ángel, M. (2006). Algunos aspectos biológicos y del manejo en cautiverio de la sabaleta Brycon henni Eigenmann, 1913 (Pisces: Characidae). Revista Colombiana de Ciencias Pecuarias, 19, 180-186.

Oliveira, R.C., Santos, M.C.F., Bernardino, G., Hrbek, T., \& Farias, I.P. (2018). From river to farm: An evaluation of genetic diversity in wild and aquaculture stocks of Brycon amazonicus (Spix \& Agassiz, 1829), Characidae, Bryconinae. Hydrobiologia, 805(1), 75-88. DOI: https://doi.org/10.1007/s10750-017-3278-0

Panarari-Antunes, R. de S., Prioli, A.J., Prioli, S.M.A.P., Galdino, A.S., Julio Jr., H.F., \& Prioli, L.M. (2011). Genetic variability of Brycon orbignyanus (Valenciennes, 1850) (Characiformes: Characidae) in cultivated and natural populations of the upper Paraná river, and implications for the conservation of the species. Brazilian Archives of Biology and Technology, 54(4), 839-848. DOI: https://doi.org/10.1590/ S1516-89132011000400025

Pareja-Carmona, M.I., Jiménez-Segura, L.F., Villa-Navarro, F.A., Reinoso-Flórez, G., Gualtero-Leal, D.M., \& Ángel-Rrojas, V.J. (2014). Áreas de reproducción de peces migratorios en la cuenca alta del Río Magdalena, Colombia. Biota Colombiana, 15(2), 40-53.

Peakall, R., \& Smouse, P.E. (2006). GENALEX 6: Genetic analysis in Excel, population genetic software for teaching and research. Molecular 
Ecology Notes, 6(1), 288-295. DOI: https://doi. org/10.1111/j.1471-8286.2005.01155.x

Pineda, H., Arboleda-Chacón, L., Echeverri-Echavarría, A., Urcuqui, S., Pareja, D., Olivera-Ángel, M., ... Builes, J. (2007). Caracterización de la diversidad genética en el pez Brycon henni (Characiformes: Characidae) en Colombia central por medio de marcadores RAPD. Revista de Biología Tropical, 55(34), 1025-1035.

Povh, J.A., Lopera Barrero, N.M., Ribeiro, R.P., Lupchinski Jr., E., Gomes, P.C., \& Lopes, T.S. (2008). Monitoreo genético en programas de repoblamiento de peces mediante marcadores moleculares. Ciencia e Investigación Agraria, 35(1), 5-15. DOI: https://doi. org/10.4067/S0718-16202008000100001

Primmer, R.C., Painter, N.J., Koskinen, T.M., Palo, U.J., \& Merilä, J. (2005). Factors affecting avian crossspecies microsatellite amplification. Journal of Avian Biology, 36(4), 348-360.

Pritchard, J.K., Stephens, M., \& Donnelly, P. (2000). Inference of population structure using multilocus genotype data. Genetics, 155, 945-959.

Rice, W.R. (1989). Analyzing tables of statistical tests. Evolution, 43, 223-225.

Rosenberg, N.A. (2004). Distruct: a program for the graphical display of population structure. Molecular Ecology Notes, 4, 137-138. DOI: https://doi. org/10.1046/j.1471-8286.2003.00566.x

Rotmistrovsky, K., Jang, W., \& Schuler, G.D. (2004). A web server for performing electronic PCR. Nucleic Acids Research, 32, 108-112. DOI: https://doi. org/10.1093/nar/gkh450

Rozen, S., \& Skaletsky, H. (2000). Primer3 on the World Wide Web for general users and for biologist programmers. In S. Krawetz \& S. Misener (Eds.), Bioinformatics Methods and Protocols: Methods in Molecular Biology (pp. 365-386). New Jersey, United States: Humana Press.

Rutkowski, R., Sielezniew, M., \& Szostak, A. (2009). Contrasting levels of polymorphism in cross-amplified microsatellites in two endangered xerothermophilous, obligatorily myrmecophilous, butterflies of the genus Phengaris (Maculinea) (Lepidoptera: Lycaenidae). European Journal of Entomology, 106(4), 457-469. DOI: https://doi.org/10.14411/eje.2009.058

Sambrook, J., Fritsch, E.F., \& Maniatis, T. (2001). Molecular cloning: A laboratory manual (3rd Edition). New York, United States: Cold Spring Harbor Laboratory Press.

Sanches, A., \& Galetti Jr., P.M. (2007). Genetic evidence of population structuring in the neotropical freshwater fish Brycon hilarii (Valenciennes, 1850). Brazilian Journal of Biology, 67(4 Suppl), 889-895. DOI: https://doi.org/10.1590/S1519-69842007000500012

Sanches, A., \& Galetti Jr., P.M. (2012). Population genetic structure revealed by a school of the freshwater migratory fish, Brycon hilarii. Latin American Journal of Aquatic Research, 40(2), 408-417. DOI: https://doi.org/10.3856/vol40-issue2-fulltext-15

Sanches, A., Galetti Jr., P.M., Galzerani, F., Derazo, J., Cutilak Bianchi, B., \& Hatanaka, T. (2012). Genetic population structure of two migratory freshwater fish species (Brycon orthotaenia and Prochilodus argenteus) from the Sao Francisco River in Brazil and its significance for conservation. Latin American Journal of Aquatic Research, 40(1), 177-186. DOI: https://doi.org/10.3856/vol40-issue1-fulltext-17

Schoebel, C.N., Brodbeck, S., Buehler, D., Cornejo, C., Gajurel, J., Hartikainen, H., ... Csencsics, D. (2013). Lessons learned from microsatellite development for nonmodel organisms using 454 pyrosequencing. Journal of Evolutionary Biology, 26(3), 600-611. DOI: https://doi.org/10.1111/jeb.12077

Simpson, J.T., Wong, K., Jackman, S.D., Schein, J.E., Jones, S.J., \& Birol, I. (2009). ABySS: A parallel assembler for short read sequence data genome research. Genome Research, 19(6), 1117-1123. DOI: https://doi.org/10.1101/gr.089532.108

van Oosterhout, C., Hutchinson, W.F., Wills, D.P.M., \& Shipley, P. (2004). Micro-Checker: Software for identifying and correcting genotyping errors in microsatellite data. Molecular Ecology Notes, 4(3), 535-538. DOI: https://doi.org/10.1111/j.1471-8286.2004.00684.x

Viana, P.M. de F., \& Vasconcelos de Macêdo, J.L. (2016). First set of polymorphic microsatellite markers for Brycon orbignyanus, anendangered neotropical piracema fish species. Conservation Genetics Resources, 8(1), 43-81. DOI: https://doi.org/10.1007/ s12686-016-0522-2

Wasko, A.P., \& Galetti Jr., P.M. (2002). RAPD analysis in the Neotropical fish Brycon lundii: Genetic diversity and its implications for the conservation of the species. Hydrobiologia, 474(1-3), 131-137. DOI: https:// doi.org/10.1023/A:1016569919615

Yue, G.H., Balazs, K., \& Laszlo, O. (2010). A new problem with cross-species amplification of microsatellites: Generation of non-homologous products. Zoological Research, 31(2), 131-140. DOI: https:// doi.org/10.3724/SP.J.1141.2010.02131

Zaniboni-Filho, E., Reynalte-Tataje, D., \& Weingartner, M. (2006). Potencialidad del género Brycon en la piscicultura brasileña. Revista Colombiana de Ciencias Pecuarias, 19(2), 233-240. 